\title{
SKRINING FITOKIMIA DAN UJI STABILITAS SEDIAAN SIRUP KAYU KUNING (Arcangelisia flava) UNTUK MEMELIHARA KESEHATAN
}

\author{
Dewi Ratnasari ${ }^{*}$, Reti Puji Handayani2 \\ ${ }_{1,2}$ Sekolah Tinggi Ilmu Kesehatan Holistik \\ *Korespondensi: Jl. Veteran No.272 Ciseureuh Purwakarta, Email: dewiratnasari@stikesholistic.ac.id
}

\begin{abstract}
ABSTRAK
Latar Belakang: Banyak penelitian menggali mengenai efektivitas dan khasiat kayu kuning, sementara untuk skrining fitokimia dengan metode dekoksi dan pembuatan sediaan belum banyak dilakukan. Kayu kuning secara empiris biasanya diminum dalam keadaan segar, segera setelah direbus, namum karena rasa yang pahit maka perlu ditutupi oleh rasa manis serta dibuat sediaan yang dapat bertahan lama. Pemilihan madu dalam penelitian dimaksudkan menambah cita rasa agar sediaan dapat dikonsumsi dalam upaya pemeliharan kesehatan.

Tujuan Penelitian: Penelitian ini bertujuan menentukan kandungan metabolit sekunder dengan metode dekoksi, membuat sediaan kayu kuning dan mengetahui stabilitas sediaankayu kuning.

Metode: Kayu kuning diekstraksi dengan metode dekoksi, diuji kandungan metabolit sekundernya, kemudian ekstrak kayu kuning ditambah madu dan diuji organoleptisnya selama 14 hari.

Simpulan: Hasil skrining fitokimia dengan metode dekoksi menunjukkan bahwa ekstrak kayu kuning mengandung alkaloid dan saponin, dan hasil uji stabilitas menunjukkan sediaan kayu kuning yang ditambah madu lebih tahan lama dibandingkan dengan sediaan kayu kuning yang tidak ditambahkan madu.
\end{abstract}

Kata kunci: kayu kuning, skrining fitokimia, madu, dekoksi

\begin{abstract}
Background: There are many studies explore the effectiveness and efficacy of yellow root, but while for phytochemical screening with decoction method and making of product has still little bit. Empirical yellow root is usually drunk in fresh condition, immediately after boiled, but cause of the bitter taste it needs to be covered by sweet taste and made product that can be last long. Options of honey for this research is intended to increase the taste of product that can be consumed in maintain health.

Objective: This research is aimed to determine secondary metabolite content by decoction method, to make yellow root product and know the stability of yellow root product.

Method: The yellow root research design used in this study is decoction method, tested the content of secondary metabolite, then added honey and tested organoleptis for 14 days.

Conclusion: The results of phytochemical screening using decoction method showed that the yellow root extract contained alkaloids and saponins, and the stability test results showed more durable yellow wood extract plus honey.
\end{abstract}

Keywords: yellow root, phytochemical screening, honey, decoction

\section{PENDAHULUAN}

Indonesia adalah negara agraris yang kaya akan keanekaragaman flora dan fauna. Hutan di Negara Indonesia menyimpan potensi yang luar biasa sebagai tempat tumbuh tanaman obat. Tanaman obat yang sudah digunakan secara empiris oleh masyarakat Indonesia, salah satunya adalah kayu kuning.
Penelitian-penelitian terkait kayu kuning sebagai tanaman obat sudah banyak dilakukan. Akar kuning berpotensi sebagai anti kanker. ${ }^{1}$ Ekstrak Kayu kuning sebagai Biopestisida, pengendalian hama. ${ }^{2}$ Penelitian lain yaitu mengenai Karakteristik dan skrining fitokimia ekstrak kering kayu kuning. Pada penelitian ini pembuatan ekstrak dilakukan dengan metode maserasi. ${ }^{3}$ 
Dari penelitian-penelitian tersebut, banyak menggali mengenai efektivitas dan khasiat kayu kuning, sementara untuk skrining fitokimia dengan metode dekoksi dan pembuatan sediaan belum banyak dilakukan. Kayu kuning secara empiris biasanya diminum dalam keadaan segar, segera setelah direbus, namun tentunya cara ini tidak efektif, karena tidak bisa dikonsumsi ketika sedang dalam perjalanan, oleh karena itu peneliti tertarik untuk membuat sediaan yang lebih praktis sehingga masih bisa mengkonsumsinya walaupun sedang tidak berada di rumah.

Rebusan kayu kuning mempunyai rasa yang pahit, sehingga tak jarang orang jadi enggan mengkonsumsinya walaupun khasiat untuk kesehatannya besar, untuk mengatasi masalah tersebut peneliti mencoba membuat sediaan dengan menambahkan madu. Madu sudah kita ketahui bersama mempunyai khasiat yang luar biasa juga untuk mengatasi berbagai penyakit ditambah dengan rasanya yang manis, sehingga masyarakat senang mengkonsumsinya. Madu adalah subtansi alam yang diproduksi oleh lebah madu yang diperoleh dari nektar bunga atau sekret tanaman yang dikumpulkan oleh lebah madu, diubah dan disimpan dalam sarang lebah untuk dimatangkan. ${ }^{4}$

Hasil penelitian terkait khasiat madu antara lain madu sebagai zat antibakteri terhadap bakteri Staphylococcus areus, ${ }^{5}$ madu sebagai antibakteri terhadap bakteri pembusuk, ${ }^{6}$ ekstrak madu mampu menghambat bakteri E.Coli 7 dan madu mempunyai aktivitas sebagai anti inflamasi, anti bakterial dan antioksidan. ${ }^{8}$ Dari uraian diatas madu terbukti secara empiris maupun ilmiah sangat bermanfaat untuk kesehatan manusia.

Dari latar belakang yang diuraikan diatas, maka masalah dalam penelitian ini yaitu bagaimana kandungan metabolit sekunder kayu kuning dengan metode dekoksi? Bagaimana pengaruh suhu terhadap stabilitas ekstrak kayu kuning? dan Bagaimana pengaruh penambahan madu terhadap stabilitas ekstrak kayu kuning? Sedangkan tujuan penelitian adalah menentukan kandungan metabolit sekunder dengan metode dekoksi, membuat sediaan kayu kuning dan mengetahui stabilitas ekstrak kayu kuning.

\section{METODE PENELITIAN}

Penelitian ini merupakan penelitian tindakan, Dilaksanakan pada bulan April, bertempat di Laboratorium Kimia, Sekolah Tinggi Ilmu Kesehatan (STIKes) Holistik Purwakarta.

\section{ALAT DAN BAHAN}

Peralatan yang digunakan dalam penelitian ini yaitu Beaker Glass, kompor gas, kaca arjoli, viskometer, pH Universal, kaca, pipet ukur, pipet tetes, tabung reaksi, rak tabung reaksi, corong kaca dan gelas ukur. Sementara bahan yang digunakan kayu kuning yang sudah dikeringkan, aquadest, madu, pereaksi Wagner, Dragendroff, Mayer, $\mathrm{HCl}$ pekat, Logam Mg, $\mathrm{H}_{2} \mathrm{SO}_{4}$ pekat, Kloroform, dan Asam Asetat anhidrat.

\section{CARA KERJA}

\section{Skrining Fitokimia}

Untuk membuat ekstrak kayu kuning metode yang digunakan yaitu Dekoksi. Dekoksi adalah suatu metode pembuatan ekstrak dengan cara dimana bagian tanaman yang berupa batang, kulit kayu, cabang, ranting, rimpang atau akar direbus dalam air mendidih dengan volume dan selama waktu tertentu kemudian didinginkan dan ditekan atau disaring untuk memisahkan cairan ekstrak dari ampasnya. Proses ini sesuai untuk mengekstrak bahan bioaktif yang dapat larut dalam air dan tahan terhadap panas. Rasio antara massa bagian tanaman dengan volume air biasanya 1:4 atau 1:16. Selama proses perebusan terjadi penguapan air perebus secara terus-menerus, sehingga volume cairan ekstrak yang diperoleh biasanya hanya seperempat dari volume semula. Ekstrak yang pekat ini selanjutnya disaring dan segera digunakan atau diproses lebih lanjut [9]. Pada penelitian yang sudah dilakukan batang kayu kuning direbus dengan $800 \mathrm{~mL}$ aquadest dan di dekoksi sampai tersisa $170 \mathrm{~mL}$.

\section{Identifikasi Alkaloid}

Identifikasi alkakoid dilakukan dengan menggunakan pereaksi Mayer, Dragendroff dan Wagner. $1 \mathrm{~mL}$ ekstrak kayu kuning ditambah dengan $1 \mathrm{~mL} \mathrm{HCl} 2 \mathrm{M}$ dan $9 \mathrm{~mL}$ Aquadest. Dipanaskan selama 2 menit, 
didinginkan kemudian disaring. Fitrat dibagi kedalam 3 tabung reaksi, dan masing-masing tabung ditetesi pereaksi Mayer, Dragendroff dan Wagner, ${ }^{10}$ kemudian diamati perubahan yang terjadi.

\section{Identifikasi Flavonoid}

Identifikasi Flavonoid dilakukan dengan cara mengencerkan ekstrak pekat kayu kuning dengan metanol kemudian dipanaskan dengan api tidak langsung, kemudian ditambahkan 0,1 gram serbuk $\mathrm{Mg}$ ditambah 5 tetes $\mathrm{HCl}$ pekat, ${ }^{10}$ kemudian diamati perubahan yang terjadi.

\section{Identifikasi Terpenoid dan Steroid}

Identifikasi Terpenoid dan steroid dilakukan dengan cara mengencerkan $1 \mathrm{~mL}$ ekstrak pekat dengan 0,5 mL Kloroform, kemudian menambahkan 0,5 mL Asam Asetat anhidrida, dan menambahkan $2 \mathrm{~mL}$ $\mathrm{H}_{2} \mathrm{SO}_{4}$ pekat secara perlahan-lahan melalui dinding tabung reaksi, ${ }^{10}$ kemudian mengamati perubahan yang terjadi.

\section{Identifikasi Saponin}

Identifikasi Saponin dilakukan dengan cara mengencerkan $1 \mathrm{~mL}$ ekstrak pekat kayu kuning dengan $9 \mathrm{~mL}$ Aquadest panas, kemudian dikocok kuat-kuat, ${ }^{10}$ dan diamati perubahan yang terjadi.

\section{Identifikasi Tanin}

Identifikasi Tanin dilakukan dengan cara mengencerkan $1 \mathrm{~mL}$ ekstrak pekat dengan $10 \mathrm{~mL}$ aquadest kemudian disaring, fitratnya ditambah larutan $\mathrm{FeCl}_{3} 1 \%{ }^{10}$ dan diamati perubahan yang terjadi.

\section{Pembuatan Sediaan dan uji Stabilitas Sediaan}

Ekstrak kayu kuning hasil dekoksi, dibagi menjadi 4 bagian dengan volume masing-masing $25 \mathrm{~mL}$.
Tabung 1 : $25 \mathrm{~mL}$ ekstrak kayu kuning, disimpan pada suhu kamar

Tabung $2: 25$ mL ekstrak kayu kuning + 5 mL madu disimpan pada suhu kamar Tabung 3 : $25 \mathrm{~mL}$ ekstrak kayu kuning, disimpan pada lemari pendingin

Tabung 4: 25 mL ekstrak kayu kuning + 5 mL madu disimpan pada lemari pendingin

Setelah itu diuji kualitasnya. Uji kualitas yang dilakukan meliputi meliputi :

\section{Uji Organoleptis}

Pengujian organoleptik dilakukan dengan mengamati sediaan ekstrak kayu kuning dari bentuk, rasa, bau, dan warna sediaan.

\section{2. $\mathbf{U j i} \mathbf{p H}$}

Tingkat keasaman atau $\mathrm{pH}$ diukur dengan menggunakan $\mathrm{pH}$ universal. Kertas pH universal dicelupkan kedalam ekstrak, warna yang terbentuk dibandingkan dengan standar.

\section{Uji Homogenitas}

Pengujian dilakukan dengan mengamati sediaan, apakah ada partikel/endapan pada ekstrak.

4. Uji stabilitas pada suhu dingin dan suhu kamar

Pengujian dilakukan dengan mengamati sediaan, apakah ada perubahan warna, rasa, bau ketika disimpan pada suhu dingin dan suhu kamar.

\section{HASIL PENELITIAN}

Kayu kuning yang digunakan dalam penelitian ini diperoleh dari Bioshop RS. Holistik Purwakarta. Kayu kuning tersebut sudah dalam keadaan kering.

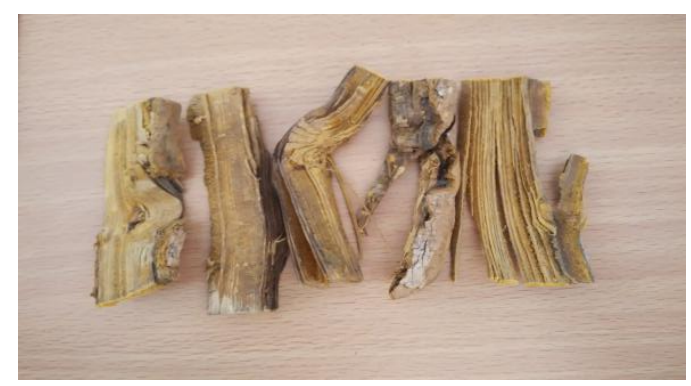

Gambar 1. Batang kayu kuning

Hasil identifikasi metabolit sekunder terhadap ekstrak kayu kuning hasil dekoksi terlihat pada Gambar 2 di bawah ini : 


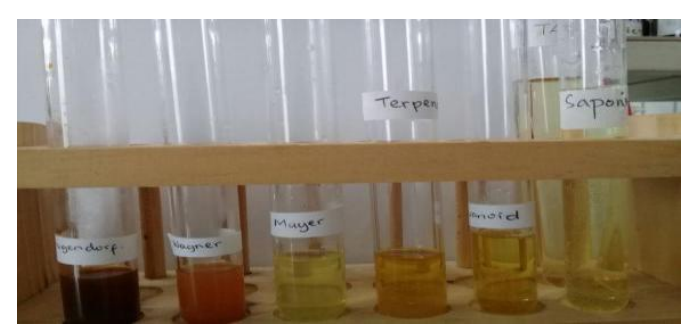

Gambar 2. Hasil Reaksi warna identifikasi metabolit sekunder ekstrak kayu kuning

Hasil uji skrining fitokimia, diperoleh data seperti yang tertera pada Tabel $1 \mathrm{di}$ bawah ini :

Tabel. 1 Hasil Skrining Fitokimia Ekstrak Kayu Kuning

\begin{tabular}{|l|l|l|c|}
\hline Uji Fitokimia & \multicolumn{1}{|c|}{ Pereaksi } & \multicolumn{1}{|c|}{ Hasil Pengamatan } & Kesimpulan \\
\hline Alkaloid & Mayer & $\begin{array}{l}\text { Tidak terbentuk } \\
\text { endapan putih }\end{array}$ & - \\
\cline { 2 - 4 } & Dragendoff & $\begin{array}{l}\text { Terbentuk endapan } \\
\text { berwarna coklat }\end{array}$ & + \\
\cline { 2 - 4 } & Wagner & $\begin{array}{l}\text { Terbentuk warna } \\
\text { coklat kemerahan }\end{array}$ & + \\
\hline Flavonoid & $\begin{array}{l}\text { Metanol + serbuk Mg }+ \\
\text { HCl pekat }\end{array}$ & $\begin{array}{l}\text { Warna larutan tetap } \\
\text { kuning terbentuk } \\
\text { gelembung udara }\end{array}$ & - \\
\hline Terpenoid & $\begin{array}{l}\text { Asam asetat anhidrida } \\
+\mathrm{H}_{2} \mathrm{SO}_{4}\end{array}$ & $\begin{array}{l}\text { Terbentuk lapisan } \\
\text { yang berwarna putih }\end{array}$ & - \\
\hline Steroid & $\begin{array}{l}\text { Asam asetat anhidrida } \\
+\mathrm{H}_{2} \mathrm{SO}_{4}\end{array}$ & $\begin{array}{l}\text { Larutan tetap } \\
\text { berwarna kuning }\end{array}$ & - \\
\hline Tanin & Aquadest $+\mathrm{FeCl}_{3} 1 \%$ & $\begin{array}{l}\text { Larutan tetap } \\
\text { berwarna kuning }\end{array}$ & - \\
\hline Saponin & Aquadest panas & $\begin{array}{l}\text { Terbentuk buih yang } \\
\text { stabil }\end{array}$ & + \\
\hline
\end{tabular}

\section{Hasil Uji Stabilitas}

Hasil uji stabilitas sediaan sirup kayu kuning terlihat pada Tabel 2 berikut :

Tabel 2. Hasil uji stabilitas ekstrak kayu kuning

\begin{tabular}{|c|c|c|c|c|c|c|c|c|}
\hline \multirow{3}{*}{$\begin{array}{c}\text { Para- } \\
\text { meter } \\
\text { yang } \\
\text { diamati }\end{array}$} & \multicolumn{8}{|c|}{$\begin{array}{lc}\text { Ekstrak Kayu Kuning } \\
\end{array}$} \\
\hline & \multicolumn{5}{|c|}{ Pada Temperatur rendah ( Dalam Lemari Pendingin) } & \multicolumn{3}{|c|}{ Pada Temperatur ruang } \\
\hline & 1 & 3 & 4 & 7 & 14 & 1 & 3 & 4 \\
\hline Warna & $\begin{array}{l}\text { Kuning } \\
\text { kecoklatan }\end{array}$ & $\begin{array}{l}\text { Kuning } \\
\text { kecoklatan }\end{array}$ & $\begin{array}{l}\text { Kuning } \\
\text { kecoklatan }\end{array}$ & $\begin{array}{l}\text { Kuning } \\
\text { kecoklatan }\end{array}$ & $\begin{array}{l}\text { Kuning } \\
\text { kecoklatan }\end{array}$ & $\begin{array}{l}\text { Kuning } \\
\text { kecoklatan }\end{array}$ & $\begin{array}{l}\text { Kuning } \\
\text { kecoklatan }\end{array}$ & $\begin{array}{l}\text { Kuning } \\
\text { kecoklatan }\end{array}$ \\
\hline$\overline{R a s a}$ & Pahit & Pahit & Pahit & Pahit & - & Pahit & - & - \\
\hline Bau & $\begin{array}{l}\text { Bau khas } \\
\text { kayu kuning }\end{array}$ & $\begin{array}{l}\text { Bau khas } \\
\text { kayu kuning }\end{array}$ & $\begin{array}{l}\text { Bau khas } \\
\text { kayu kuning }\end{array}$ & $\begin{array}{l}\text { Bau khas } \\
\text { kayu kuning }\end{array}$ & Bau tengik & $\begin{array}{l}\text { Bau khas } \\
\text { kayu kuning }\end{array}$ & $\begin{array}{l}\text { Bau khas } \\
\text { kayu } \\
\text { kuning }\end{array}$ & Bau tengik \\
\hline Bentuk & Cair & Cair & Cair & Cair & Cair & Cair & Cair & Cair \\
\hline $\mathrm{pH}$ & 5 & 5 & 5 & 5 & 5 & 5 & 5 & 5 \\
\hline $\begin{array}{l}\text { Homo- } \\
\text { genitas }\end{array}$ & Homogen & Homogen & Homogen & Homogen & Homogen & $\begin{array}{l}\text { Ada } \\
\text { Endapan }\end{array}$ & $\begin{array}{l}\text { Ada } \\
\text { endapan }\end{array}$ & $\begin{array}{l}\text { Ada } \\
\text { endapan }\end{array}$ \\
\hline
\end{tabular}


Tabel 3. Hasil Uji Stabilitas Sediaan Campuran Kayu Kuning dengan Madu

\begin{tabular}{|l|l|l|l|l|l|l|l|}
\hline $\begin{array}{c}\text { Para- } \\
\text { meter } \\
\text { yang } \\
\text { diamati }\end{array}$ & \multicolumn{7}{|c|}{ Ekstrak Kayu Kuning + Madu } \\
\cline { 2 - 8 } Hari ke- & $\mathbf{1}$ & $\mathbf{3}$ & $\mathbf{7}$ & $\mathbf{1 4}$ & $\mathbf{1}$ & $\mathbf{3}$ & $\mathbf{7}$ \\
\hline Warna & $\begin{array}{l}\text { Kuning } \\
\text { kecoklatan }\end{array}$ & $\begin{array}{l}\text { Kuning } \\
\text { kecoklatan }\end{array}$ & $\begin{array}{l}\text { Kuning } \\
\text { kecoklatan }\end{array}$ & $\begin{array}{l}\text { Kuning } \\
\text { kecoklatan }\end{array}$ & $\begin{array}{l}\text { Kuning } \\
\text { kecoklatan }\end{array}$ & $\begin{array}{l}\text { Kuning } \\
\text { kecoklatan }\end{array}$ & $\begin{array}{l}\text { Kuning } \\
\text { kecoklatan }\end{array}$ \\
\hline Rasa & $\begin{array}{l}\text { Rasa } \\
\text { pahitnya } \\
\text { berkurang }\end{array}$ & $\begin{array}{l}\text { Rasa } \\
\text { pahitnya } \\
\text { berkurang }\end{array}$ & $\begin{array}{l}\text { Rasa } \\
\text { pahitnya } \\
\text { berkurang }\end{array}$ & - & $\begin{array}{l}\text { Rasa } \\
\text { pahitnya } \\
\text { berkurang }\end{array}$ & $\begin{array}{l}\text { Rasa } \\
\text { pahitnya } \\
\text { berkurang }\end{array}$ & - \\
\hline Bau & $\begin{array}{l}\text { Bau khas } \\
\text { madu }\end{array}$ & $\begin{array}{l}\text { Bau khas } \\
\text { madu }\end{array}$ & $\begin{array}{l}\text { Bau khas } \\
\text { madu }\end{array}$ & Bau Asam & $\begin{array}{l}\text { Bau khas } \\
\text { madu }\end{array}$ & $\begin{array}{l}\text { Bau khas } \\
\text { madu }\end{array}$ & Bau Asam \\
\hline Bentuk & Cair & Cair & Cair & Cair & Cair & Cair & Cair \\
\hline pH & 5 & 5 & 5 & 5 & 5 & 5 & 5 \\
\hline $\begin{array}{l}\text { Homo- } \\
\text { genitas }\end{array}$ & Homogen & Homogen & Homogen & Homogen & Ada Endapan & $\begin{array}{l}\text { Ada } \\
\text { endapan }\end{array}$ & $\begin{array}{l}\text { Ada } \\
\text { endapan }\end{array}$ \\
\hline
\end{tabular}

\section{PEMBAHASAN PENELITIAN SKRINING FITOKIMIA}

Dari Tabel 1 diperoleh data bahwa ekstrak kayu kuning mengandung alkaloid dan saponin. Alkaloid adalah senyawa organik berbobot molekul kecil mengandung nitrogen dan memiliki efek farmakologi pada manusia dan hewan. Secara alamiah alkaloid disimpan didalam biji, buah, batang, akar, daun dan organ lain. Alkaloid biasanya diturunkan dari asam amino serta banyak alkaloid yang bersifat racun, namun alkaloid juga banyak ditemukan untuk pengobatan. ${ }^{9}$ Alkaloid mempunyai khasiat sebagai anti bakteri, anti diabetes, anti malaria dan anti mikroba 11 sehingga kayu kuning merupakan tanaman obat.

Identifikasi alkaloid dilakukan dengan menggunakan 3 pereaksi, yaitu pereaksi Wagner, pereaksi Mayer dan pereaksi dragendroff. Larutan Mayer terdiri dari $\mathrm{HgCl}_{2}$ dan $\mathrm{KI}$, pereaksi Dragendorf merupakan campuran Bismuth subnitrat, asam asetat glasial dan KI sementara pereaksi Wagner merupakan campuran KI dan Iodine. ${ }^{9}$

Hasil identifikasi alkaloid dengan pereaksi wagner ditandai dengan terbentuknya endapan berwarna coklat kemerahan, hal ini disebabkan karena terjadinya reaksi antara alkaloid dengan larutan $\mathrm{I}_{2}$ dalam $\mathrm{KI}$, yang membentuk senyawa Kalium-Alkaloid, sedangkan uji alkaloid dengan pereaksi dragendroff juga menghasilkan senyawa Kalium-Alkaoid yang ditandai dengan terbentuknya endapan berwarna coklat. ${ }^{10}$

Hasil penelitian juga menunjukkan bahwa ekstrak kayu kuning mengandung saponin, yang ditandai karena terbentuknya buih ketika dikocok. Terbentuknya buih menunjukkan kemampuan menurunkan tegangan permukaan yang disebabkan molekul saponin terdiri dari hidrofor dan hidrofil. Bagian hidrofob adalah aglikonnya, bagian hidrofil adalah glikonnya. Saponin akan memberikan rasa pahit atau getir. ${ }^{12}$

\section{UJI STABILITAS}

Dari Tabel 2 didapat data bahwa ekstrak kayu kuning dapat tahan pada temperatur dingin selama 14 hari, sedangkan pada temperatur ruang hanya bertahan selama 3 hari, ditandai dengan berubah bau dari ekstrak kayu kuning tersebut, asalnya berbau khas kayu kuning menjadi berbau tengik, yang mengindikasikan telah terjadi perubahan sifat organoleptis, perubahan sifat organoleptis pada umumnya akan diikuti oleh perubahan kimia atau terjadinya perubahan komponen dalam ekstrak tersebut. ${ }^{13}$

Pada Tabel 3 diperoleh data bahwa penambahan madu ternyata memberikan efek stabilitas yang lebih lama dibandingkan ekstrak tanpa madu, hal ini dikarenakan madu memiliki sifat antibakteri, khususnya terhadap bakteri staphicoccus aureus ${ }^{5}$ sehingga bakteri tidak 
dapat hidup dan berkembang di dalam madu, hal lain yang menyebabkan madu berfungsi sebagai antibakteri karena madu mengandung unsur kalium yaitu unsur yang mencegah kelembaban sehingga dapat menghambat pertumbuhan bakteri. ${ }^{14}$ Selain penambahan madu, suhu penyimpananpun berpengaruh terhadap ketahanan ekstrak kayu kuning. Faktor yang sangat berpengaruh terhadap pertumbuhan mikroorganisme yaitu suhu, konsentrasi substrat, waktu inkubasi, dan $\mathrm{pH}$. Pada temperatur rendah bakteri nonaktif, sedangkan pada suhu tinggi akan mengalami denaturasi protein sehingga proses metabolismenya akan terhenti, ${ }^{15}$ namun $\mathrm{pH}$ tidak menunjukkan perubahan yang signifikan walaupun terjadi perubahan bau, dikarenakan pengukurannya menggunakan $\mathrm{pH}$ universal, sehingga kemungkinan penurunan $\mathrm{pH}$ tidak ada terukur secara akurat.

\section{SIMPULAN}

Hasil skrining fitokimia dengan metode dekoksi batang kayu kuning diperoleh data bahwa ekstrak kayu kuning mengandung alkaloid dan saponin, dan dari hasil uji stabilitas diperoleh bahwa sediaan kayu kuning dengan penambahan madu lebih tahan lama dibanding sediaan kayu kuning tanpa madu.

\section{DAFTAR PUSTAKA}

1. Pratama, M.R.F. 2016. Akar Kuning (Arcangelisia flava) Sebagai Inhibitor EGFR : Kajian in Silico. Universitas Muhammadiyah Palangkaraya, Indonesia.

2. Budiasti, R. 2016. Pengaruh Pemberian Ekstrak Batang Kayu Kuning (Arcangelisia flava (L) Merr.) Sebagai Biopestisida Pengendalian Hama Plutella Sylostella Pada Tanaman Sawi (Brassica juncea (L)). Jurnal Biologi Vol 5 No.3.

3. Marpaung, M.P., Ahwizar, A., Wulandari, W. 2017. Karakteristik dan Skrining Fitokimia Ekstrak Kering Akar Kuning ( Fibraurea chloroleuca Miers). Prosiding Seminar Nasional Kimia UNY.

4. W. Elsi, R. Rosiaili dan A. Yustini. (2014). Perbandingan Daya Hambat Madu Alami dengan Madu Kemasan secara In Vitro terhadap Streptococcus beta hemoliticus Group A sebagai Penyebab Faringitis. http://jurnal.fk.unand.ac.id

5. Nadhila, N.F.,__. The Avtivity of Antibacterial Agent of Honey Againt Staphylococcus aureus. Faculty of Medicine, University of Lampung. [Artikel Review].

6. Andriani, MAM., Utami, R., Hariyati, L.F.___ Aktivitas Antibakteri Berbagai Jenis Madu Terhadap Bakteri Pembusuk (Pseudomonas Fluorescens FNCC 0071 dan Pseudomonas putida FNCC 0070. Jurusan Teknik Hasil Pertanian. Universitas Sebelas Maret.

7. Wardhana, B.K., 2014. Efektivitas Ekstrak Madu Karet Dalam Menghambat Pertumbuhan Bakteri E.Coli. Laporan penelitian. Universitas Islam Negeri Syarif Hidayatullah. Jakarta.

8. Gunawan, N.A. 2017. Madu : Efektivitasnya untuk perawatan luka. CDK-249/ Vol. 44 No. 2.

9. Endriani, L.H., 2016. Farmakognosi dan Fitokimia. Modul Cetak Bahan Ajar Farmasi, Kementrian Kesehatan Republik Indonesia, PPSDMK. Badan Pengembangan Dan Pemberdayaan Sumber Daya Manusia Kesehatan.

10. Setyowati, W.A.E, dkk., 2014. Skrining Fitokimia dan Identifikasi Komponen Utama Ekstrak Metanol Kulit Durian (Durio zibenithus Murr) Varietas Petruk. Seminar Nasional Kimia dan Pendidikan Kimia VI. Pemantapan Riset Kimia dan Assesmen dalam Pembelajaran Berbasis Pendekatan Saintifik. ISBN 979363174-0.

11. Ningrum, R., Purwanti, E., dan Sukarsono. 2016. Identifikasi Senyawa Alkaloid dari Batang Karamunting ( Rhodomyrtus tomentosa) sebagai Bahan Ajar Biologi Untuk SMA KELAS X. Jurnal Pendidikan Biologi Indonesia p-ISSN : 2442-3750; e-ISSN: 2527-6204). Volume 2 Nomor 3 Tahun 2016, hal 231-236.

12. Sirait, M. 2007. Penuntun Fitokimia dalam Farmasi. Bandung : Penerbit ITB.

13. Ulfa, E.U dan Rachmawati, E. Standarisasi Ekstrak Batang Kayu 
Journal of Holistic and $\mathrm{Health} \mathrm{Sc}$ iences

Vol.2, No.1, Januari-juni 2018 | 13

Kuning ( Arcangelisia flava (L.) Merr). Fakultas Farmasi. Universitas Jember.

14. Rio, Y.B. P, Djamal, A., dan Asterina. Perbandingan Efek Antibakteri Madu Asli Sikabu dengan madu Lubuk Minturun terhadap Escherichia Coli dan
Staphylococcus aureus secara In Vitro. Jurnal Kesehatan Andalan, 2012 . 1 (2). http ://jurnal.fk.unand.ac.id

15. Suruawiria, U. 2003. Mikrobiologi Air dan Dasar-Dasar Pengolahan Buangan Secara Biologis. PT. Alumni, Bandung 